\title{
Small scale 100 ha logging concessions' contribution to regional finance: Case study in Bulungan district
}

\author{
By Samsu, Heru Komarudin, Sian McGrath, Yan Ngau and Dt. Iman Suramenggala
}

IPPK: an economy-oriented policy Following the collapse of Soeharto's regime, Indonesia granted district governments more control over managing natural resources, and significantly increased their share of rents from forestry. National decentralization laws introduced in 1999 gave district heads (Bupatis) the authority to issue logging permits for concessions smaller than 100 ha. The policy applied only to production forests zoned for conversion to other uses, and excluded areas where concessions had already been granted. Despite this limitation, across Indonesia almost all districts with forests took immediate advantage of their new powers. This right has since been cancelled by the Ministry of Forestry ${ }^{1}$

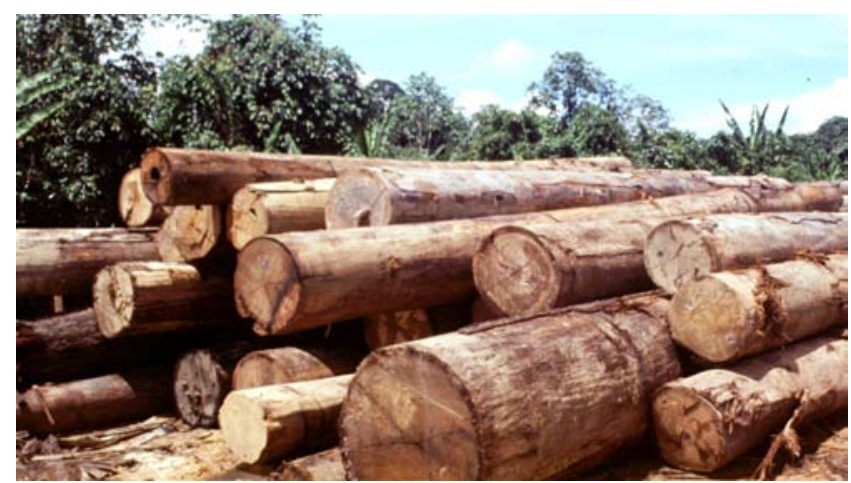

Logging timber in Bulungan district, East Kalimantan.

(Photo by Yani Saloh) and by 2003 almost all districts had stopped issuing local small-scale licenses.

The national objective was to strengthen district economies and increase efficiency, effectiveness and accountability in public sector forest management. The national framework for fiscal decentralization ${ }^{2}$ says regional income sources should include regionally generated revenues (PAD), nationally shared income, regional loans and "other incomes considered valid and legal"'.

According to national law, districts had to introduce their own regulations, or "Perda" governing small-scale concession management. Local Bupatis can also issue decrees governing small concessions. These are lesser regulations that do not have to be debated and passed by the District House of Representatives (DPRD).

The Bupati of Indonesia's Bulungan district acted quickly on the 1999 ministerial decree authorizing local governments to issue small-scale concessions ${ }^{4}$. On 28 June 2000, the Bupati issued a "Granting Licence for Utilising Forest Products" decree ${ }^{5}$ covering areas outside the official state-owned forest estate. These are classified as private, community and customary (adat) forests.

Bulungan's Perda No. 17, on Retributions Derived from Granting Licenses for Utilizing Forest Products in private and community forests followed on 2 November $2000^{6}$. This Perda sets out the district's policy on collecting payments from small-scale concession permits - known locally as IPPK 100 ha permits.

In addition to increasing the opportunities for local communities to benefit from forest resources, Bulungan's policy was aimed at increasing the district's locally-generated revenue (PAD). The Bupati's decree covers issues such as site selection, environmental and social impacts, whereas higher, district regulations (Perda) govern revenue collection. This indicates the priority placed on economic considerations, as only the regulation for collecting revenue was presented to the District House of Representatives (DPRD) for approval. It meant local people only had an opportunity to comment on economic considerations - not social and environmental issues. For a short while, the district government was also able to boost regionally generated forestry revenue (PAD) 
by raising rents on logs exported directly from private and community-owned forests in the district. The Bupati issued two special regulations to this effect in $2001^{7}$ but the regulations were revoked after seven months by a joint decree from the Ministers of Forestry and the Minister of Industry and Trade. This ministerial decree banned direct log and chip exports from all districts ${ }^{8}$.

Local communities welcomed this national decentralization policy. Bulungan communities entered into partnerships with investors and forest concessionaires, who then applied for permits on their behalf, as the communities lack the capital and capacity to apply for and manage a concession on their own. Demand for IPPK 100 ha permits was high, due to a number of factors: the application process was simple, quick and easy; only a small amount of capital was required in return for quick cash turnovers and supplies of legal timber; and local markets for logs opened up rapidly after the introduction of the policy.

The number of permits issued in Bulungan jumped from 40 in 1999, the first year, to 585 in 2000. No new licenses were granted in 2001 , but 618 concessions were operational. Although new or extension permits were still being issued in 2002-2003, much smaller numbers were operational for a number of reasons. Firstly, the central government was putting increasing pressure on the district to stop issuing permits. Secondly the amount of available forest outside the official forest estate was reducing rapidly. Finally the Bupati stopped issuing permits in February 2004. He stated this was because he was concerned about the lack of benefits going directly to local communities whilst their forest resources were being exploited.

This policy brief considers how much the IPPK 100ha policy contributed to locally-generated revenue. Yayasan Pionir and CIFOR analyzed the Bulungan district government' provisions for revenue collection and administration. We also examined the number of permits issued and the amount of wood harvested from IPPK 100 ha concession areas, and compared this with the district's forest revenue receipts and expenditures reflected in the regional budget. This analysis provides key recommendations for improving accountability and transparency in the management of forest rents at the national and district levels.

\section{How much did the IPPK 100ha policy contribute to district}

\section{revenue?}

IPPK concessions provided four sources of revenue from direct fees, levies and taxes at the district level, and fees collected by the central administration and redistributed using national fiscal balancing mechanisms:

\section{District Revenues}

1. IPPK Timber Concession Contribution. Interestingly, District Regulation 17/2000 does not regulate this contribution. Instead, the regulation refers to an earlier District Regulation (also No.17) issued in $1998^{\circ}$ which stipulates a mechanism for the collection of third-party contributions or "sumbangan pihak ketiga" from various commercial actitivities, including forest concessions. This one-off payment for a forest concession license was set at Rp. 200.000/ha. A third party contribution is a voluntary contribution. Our research showed that companies did not always pay; in 2000 and 2001, records show that only 59 out of 618 concessionaires paid this contribution.

2. IPPK Log Export Tax (Retribusi Ekspor Kayu Bulat). Although this tax only prevailed for 7 months, it generated a significant amount of district income (Rp. 7.6 billion). Export tariffs are set according to the volume and type of log exported. For example, the tariff for dipterocarps was Rp. $120,000 / \mathrm{m}^{3}$.

3. IPPK Log Tax (Retribusi Kayu Bulat). This is a volume-based royalty on each cubic meter of timber harvested, such as Rp. $25,000 / \mathrm{m}^{3}$ for mixed timber, Rp. $60,000 / \mathrm{m}^{3}$ for dipterocarp spesies and Rp. $75,000 / \mathrm{m}^{3}$ for the most valuable timber.

Table 1. Regional income from IPPK Timber Concession Fees and IPPK Log Tax

\begin{tabular}{|c|c|c|c|c|c|c|c|}
\hline \multirow[t]{2}{*}{ No. } & \multirow[t]{2}{*}{ Year } & \multirow{2}{*}{$\begin{array}{c}\text { Number of Permits } \\
\text { Operational } \\
\text { (cumulative) }\end{array}$} & \multirow[t]{2}{*}{ Area (ha) } & \multirow[t]{2}{*}{$\begin{array}{l}\text { Production } \\
\qquad\left(\mathrm{m}^{3}\right)\end{array}$} & \multicolumn{2}{|c|}{$\begin{array}{c}\text { Revenues Received } \\
\text { (Rp. 000) }\end{array}$} & \multirow[t]{2}{*}{$\begin{array}{l}\text { Total amount } \\
\text { (Rp. 000) }\end{array}$} \\
\hline & & & & & $\begin{array}{c}\text { Timber } \\
\text { Concession } \\
\text { Contribution }\end{array}$ & $\log \operatorname{Tax}$ & \\
\hline 1. & 1999 & 39 & 3,740 & - & - & - & \\
\hline 2. & 2000 & 585 & 58,444 & $171,939.09$ & $2,034,955$ & 266.426 & $2,301,381$ \\
\hline 3. & 2001 & 618 & 62,940 & $809,785.15$ & $5,791,645$ & $2,953,539$ & $8,745,184$ \\
\hline 4. & 2002 & 188 & 18,689 & $226,612.39$ & $1,267,500$ & 237,868 & $1,505,368$ \\
\hline 5. & 2003 & 189 & 18,234 & $404,214.22$ & 302,000 & 187,806 & 489,806 \\
\hline
\end{tabular}

Source: Regional Income Service Office of Bulungan District (Kantor Dinas Pendapatan Daerah Kab. Bulungan) 
Table 2. IPPK's contribution to DR and PSDH paid to central government and regional income from DAK-DR and PSDH, for seven of Bulungan's 13 subdistricts. ${ }^{13}$

\begin{tabular}{|c|c|c|c|c|c|c|}
\hline \multirow[t]{2}{*}{ Year } & \multirow[t]{2}{*}{$\begin{array}{l}\text { Production } \\
\qquad\left(\mathrm{m}^{3}\right)\end{array}$} & \multirow[t]{2}{*}{$\begin{array}{c}\mathrm{DR}^{*} \\
(\text { Rp. 000) }\end{array}$} & \multirow[t]{2}{*}{$\begin{array}{c}\text { PSDH } \\
\text { (Rp. 000) }\end{array}$} & \multirow[t]{2}{*}{$\begin{array}{c}\text { Total amount } \\
\text { (DR+PSDH) } \\
\text { (Rp. 000) } \\
\end{array}$} & \multicolumn{2}{|c|}{$\begin{array}{l}\text { Regional income from } \\
\text { shared revenues } \\
\text { (Rp. 000) }\end{array}$} \\
\hline & & & & & DAK -DR & PSDH \\
\hline 2000 & $129,024.19$ & $1,951,310$ & $1,105,543$ & $3,056,853$ & - & - \\
\hline 2001 & $538,134.96$ & $15,706,025$ & $7,324,453$ & $23,030,478$ & $17,606,565$ & $3,726,945$ \\
\hline 2002 & $226,612.39$ & $27,300,175$ & $12,623,724$ & $39,923,899$ & $4,904,112$ & $5,488,349$ \\
\hline 2003 & $404.214,22$ & $64,392,271$ & $19,991,499$ & $84,383,770$ & $30,397,515$ & $21,194,115$ \\
\hline
\end{tabular}

Source: Technical Implementation Unit of the Provincial Forestry Office (UPTD Kehutanan Bulungan) (2003). The total amount is receipts of DR and PSDH sourced from timber production of IPPK in Bulungan district Bulungan. * Conversion from US\$ assuming a rate of 8,500Rp. Table does not include large scale HPH forest concessions issued by the centre.

\section{Shared Revenues}

4. National Forest Resource Rent Provisions (PSDH) and the Reforestation Fee (DR). These fees are also payable to the central administration on IPPK concessions. The central administration retains $20 \%$ of the PSDH, and distributes the remainder back across the districts and province. The province receives $16 \%$, Bulungan receives $32 \%$, and the remaining $32 \%$ of the $\mathrm{PSDH}^{10}$ is distributed among all the other districts in East Kalimantan. Of the DR, the central administration should return $40 \%$ to East Kalimantan Province, as the producing region, which will then share portion of the funds to Bulungan. The remaining $60 \%$ is distributed to non-producing and timber producing districts.

The total IPPK policy's contribution (from districtgenerated and shared revenues) was only $2.5 \%$ of the total regional income (Rp. 95.5 billion) in 2000. Its contribution in 2001, when the district imposed tariffs on log exports for seven months, increased to $3.9 \%$ of the total budget (Rp. 413 billion). The proportion of regional budget contributed from IPPK decreased sharply to $0.26 \%$ of the total budget (Rp. 587 billion) in 2002.

The IPPK policy significantly contributed to districtgenerated revenue. In 1999, the total districtgenerated revenue was less than Rp. 2 billion. In 2000, this went up to Rp. 4.7 billion, and IPPK revenues contributed almost $50 \%$ (Rp. 2.3 billion) of this total annual budget. Income from IPPK timber concession contributions and log tax alone increased sharply in 2001 to Rp. 8.7 billion, this time contributing $39.7 \%$ of the district generated budget (PAD) (Rp. 21.9 billion). If the revenue of Rp. 7.6 billion received from log export is included ${ }^{11}$, the total contribution of the IPPK in 2001 constituted $74 \%$ of the PAD.

In addition to district generated budgets (PAD), the IPPK policy also contributed significantly to regional income from shared revenues. These were levied on IPPK concession holders and the central government then transferred a proportion back to the districts.
The total receipts from shared revenues under DAK-DR were Rp. 17.6 billion in 2001, Rp. 4.9 billion in 2002 and Rp. 30.4 billion in 2003.

\section{Facts Behind the Recorded and Actual Receipts Due}

We calculated that higher district revenue was due from small-scale logging concessions than the amounts officially documented in the district revenue office (Dispenda) (Table 1). Our calculations were based on the number of permits issued and the volume of timber produced from IPPK concessions, the total receipts due from the one-off, voluntary IPPK Timber Concession Contribution, and the short-lived IPPK Log Tax.

For Bulungan (excluding Sesayap, Sesayap Hilir, Bunyu and Tanah Lia subdistricts), for example, the total log production was recorded as $1,612,550.85 \mathrm{~m}^{3}$ for 2000 and 2003. Therefore, the Bulungan district government should have received IPPK Log Tax of between Rp. 40.3 billion and Rp. 96.7 billion. However, the receipts recorded in the district budget only amounted to Rp. 11 billion (Table 1). Assuming that the fee charged for dipterocarps was Rp. $60,000 / \mathrm{m}^{3}$ and Rp. $25,000 / \mathrm{m}^{3}$ for other species, the receipts should have ranged between Rp. 29.1 billions - Rp. 85.5 billions. Similar discrepancies appeared between the amount due from timber concession contributions and the amount actually recorded in the district budget. The difference between what should have been paid and what was paid came to a total of Rp. 3 billion during 2000-2003.

One possible reason for the discrepancy was poor coordination between the processes for collecting district level taxes and the process for authorizing timber transportation. Based on the prevailing ${ }^{13}$ national regulations, permit holders can only market and transport logs once they have received a letter from a licensing officer in the forestry office, 


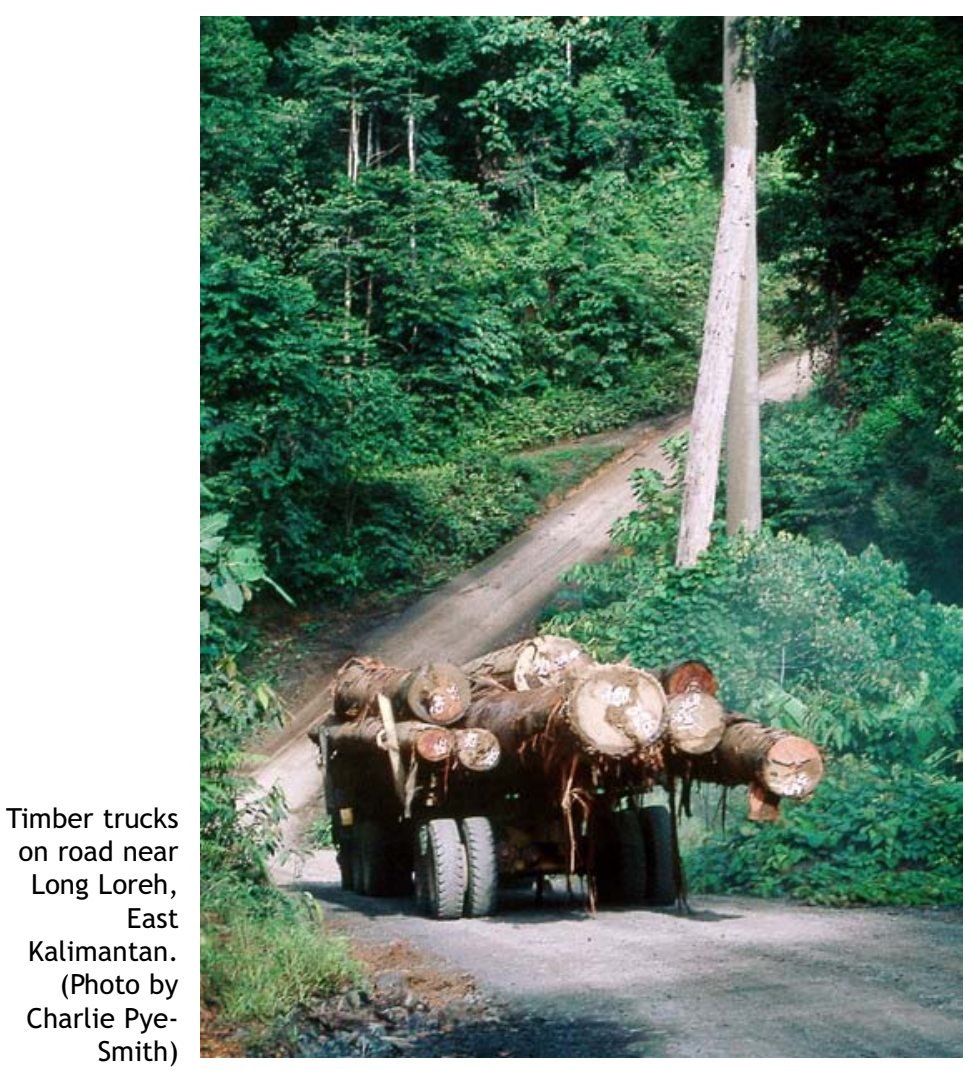

authorizing timber transportation (SKSHH). District regulation No. $17 / 2000$ does not clearly stipulate the mechanisms and processes for revenue collection and payments. Article 9 of the regulation mentions that specific mechanisms and processes would be stipulated in a Bupati's Decree. However, no decree specifying mechanisms and processes was ever issued.

The process for collecting district Log tax was not effective. The province issues an SKSHH to concessionaires once they have paid national taxes. This left the district revenue office (Dispenda) with no mechanism to ensure local taxes were paid. District regulation No. $17 / 2000^{14}$ did stipulate administrative and even criminal sanctions for non-payment. In law, permit holders who did not pay District Log Tax on time should have been charged $2 \%$ interest on the tax due for every month of delay. Those who ignored their tax obligations faced at least 6 months in prison or a fine four times the value of the unpaid tax. In practice the sanctions were never applied.

This unclear process for collecting taxes could be part of the reason that there was a difference between the income due to the district and the actual income received and officially recorded. As there were no effective means for enforcing district tax payment, or improving coordination between the various agencies responsible for regulating tax payments to the district and national accounts. During a workshop organized by Yayasan Pionir, CIFOR and the district government on May 6, 2004, participants agreed that there was very weak coordination between agencies in the provincial and the district Forestry Offices in regulating and controlling forest management and revenues. There was a consensus that coordination was especially weak in relation to the processes for authorizing timber transportation (SKSHH issuance) and tax collection. Examples were given of how the confusing hierarchy and unclear divisions of roles and obligations between different government agencies had caused delays in invoicing, collecting and recording payments from permit holders.

The policy-making process itself was another source of confusion. For example, the Bulungan Bupati issued a decree $^{15}$ authorizing IPPK 100 ha permit issuance before the district House of Representatives considered and passed regulations on the process for paying and collecting forestry revenue. In addition, although the Bupati issued a regulation ${ }^{16}$ in 2000 establishing the district forestry office, the necessary implementing regulations laying out the office's function, roles and responsibilities were not passed until the Head of District Forestry Offices circulated a letter in January $2003^{17}$. This lead to confusions and overlaps because the IPPK permits continued to be issued - although there was no legal clarity on which office should regulate payments of forestry levies, monitoring and supervision of forest concessions, production reporting, etc.

Finally, there was also a lack capacity for financial administration at the district level. There were not enough qualified district officers, and the officers that did work on financial administration lacked experience and training.

Delivering accountable, controlled, efficient, effective and transparent financial management in the forestry sector at the district level has been an uneasy challenge in the decentralization era.

\section{The Future}

When the central government first tried to revoke district Bupatis' authority to issue 100ha community logging permits in 2000, a long dispute followed. Bulungan's Bupati argued that the IPPK policy was benefiting local communities, and therefore it represented a much better system than the previous $\mathrm{HPH}$ permit allocation system. Local stakeholders also argued that Law No. 22 on decentralization gave districts responsibility for natural resource management; and because a Law is a higher regulation than a Ministerial Decree or a national government regulation, districts should have retained the right to issue local permits. Bulungan's IPPK policy was officially terminated February 20, 2004, under a special decree from the Bupati ${ }^{18}$. The termination will have a significant impact on district generated income (PAD). 
Following what they see as attempts to recentralize control over forestry, the Bulungan government will continue to try and identify new revenue sources to finance regional governance and development. The district government has recently begun to consider oil palm plantation permits - mostly located in the logged over IPPK concessions - as an option ${ }^{19}$. However, this does not look promising. Of the nine licenses issued since the start of 2004, the Bupati revoked five because the company failed to fulfil administrative requirements and to start initial operations such as land clearing and planting ${ }^{20}$. In addition to this, our GIS analysis demonstrated that $69.7 \%$ of the district is actually unsuitable for oil palm plantation, and of the remaining land, only $21.7 \%$ is suitable for large-scale oil plantation.

IPPK permits were initially allocated on the basis that the concession areas would be replanted. Interviews with high level officials indicated that the government is also considering how it could generate income (PAD) from centrally-issued HPH concessions covering an area of 784,745 ha - almost half the total area of this district. The key question now is: to what extent will these new efforts take into account the impacts on sustaining resources for the future and maximizing revenue generation and employment from forest land in Bulungan?

One of the most important and relevant lessons is that policy and implementation failures limited the district policy's potential contribution to district generated finance (PAD). The failures arose from unclear central directives on financial management; contradictions and unclear hierarchies between district and provincial policies and functions; and inadequate mechanisms for controlling and monitoring tax payment and collection. Although the policy included administrative and criminal sanctions for delayed or non-payment of forest rents, these were never imposed. These weaknesses limited accountability and transparency, and created possible opportunities for misuse of forest rents.

Another lesson learned is that stronger provisions have to be built into the central, provincial and district's combined policy formulation and implementation to provide socio-economic benefits for local communities and sustain valuable environmental services provided by forests. For example, restoring the environment through reforestation and land rehabilitation relies on centrally transferred reforestation funds (DAK-DR) amounting to hundreds of billions of rupiah. However, the Ministry of Forestry has set rigid and inflexible rules governing how DAKDR revenues should be used. As a result, reforestation activities have not been successful. Nor is there any provision in the guidelines enabling district governments to invest funds to support local forestdependent communities to build the necessary technical and negotiation skills to sustain their resources and develop their socio-economic wellbeing ${ }^{21}$.

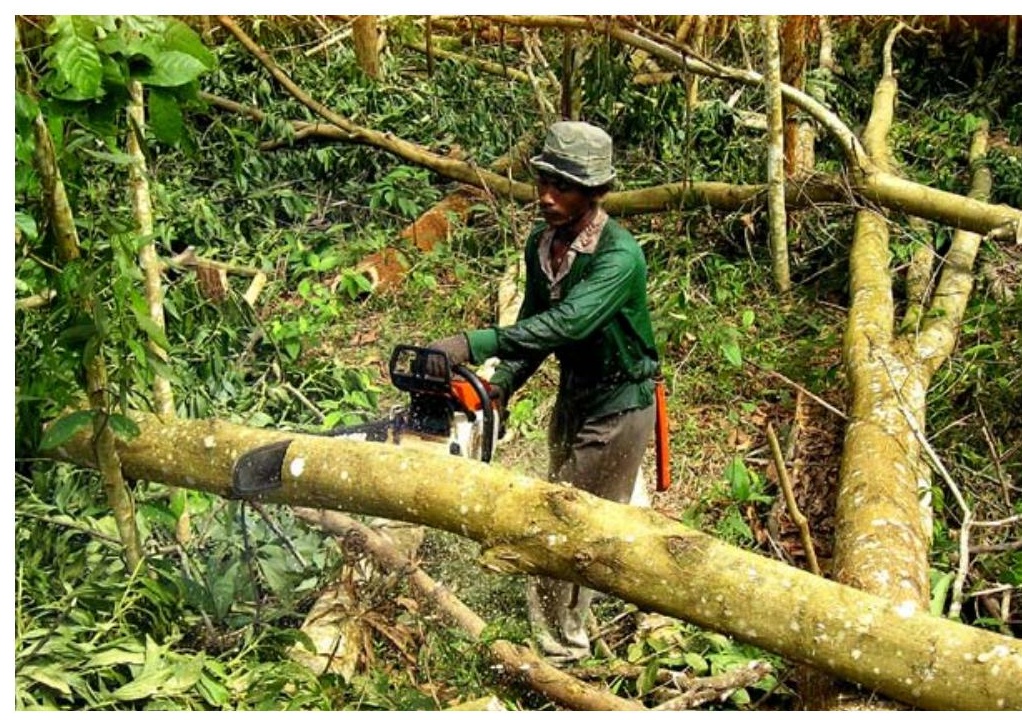

Logging harvesting by local people in East Kalimantan. (Photo By Romain Pinraid)

Thus, it will be wiser in the future to carefully consider social, economic and environmental aspects in when formulating forest policies for financial management, because they have much broader impacts at the local level than simply increasing revenue.

\section{Conclusions}

1. The IPKK policy was economically oriented to increase regional income. Its contribution in this regard was significant, but it still represented a very small proportion of the entire district budget. The district budget still depends very heavily on the allocation of shared revenues from the centre. This limits local development opportunities.

2. The IPPK policy should have contributed much more to the district budget. Unclear tax collections mechanisms and weak enforcement of sanctions limited the district's revenue from this source.

\section{Recommendations}

1. A one-stop payment system on all future permits (timber production and plantation). This would encourage permits holders to pay and make their payments on time; and reduce timber smuggling if the system was tied to the process for authorizing timber transport. When the IPKK policy was active, permit holders had to pay a minimum of five different taxes at different times to different agencies within the central, district and provincial forestry bureaucracy. A one-stop payment would reduce transaction costs and increase efficiency and transparency. This would require coordination among the related technical agencies, which may be provided by the Regional 
Income Service Office. A simpler one-off payment would also reduce confusion and therefore make it easier to demonstrate that funds are accountably managed.

2. Community participation in decision-making about allocating forest revenue, as well as monitoring and supervising the system to ensure districts receive the correct money. This would help create accountability and transparency in regional financial management, and accommodate the community's socio-economic and environmental interests.

\section{Endnotes}

${ }^{1}$ Ministerial Decree No. 6886/Kpts-II/2002.

${ }^{2}$ Law No.25/1999.

${ }^{3}$ Law No. 25/1999 Article 3.

${ }^{4}$ Decree No. 310/Kpts-II/1999 on the Guidelines for Granting Forest Product Harvesting Rights.

${ }^{5}$ Bupati's Decree No. 196 of 2000.

${ }^{6}$ It is interesting to note that the Bupati's decree setting out the policy for managing small-scale concessions stipulates that concessions can be allocated on private, community and indigenousowned, forests, but the accompanying regulation stipulating retributions that must be paid does not include indigenous-owned forests.

${ }^{7}$ Perda No. 1/2001 on Granting for the export license of log from private and community forests; and Perda No. 2/2001 on the Charge on export licenses of log from private and community forests.
8 A joint decree No. 1132/Kpts-II/2001 and No. 292/MPP/Kep/10/2001 dated 8 October 2001 on the banning of log and chip exports.

9 Perda No. 17/1998 issued on 31 October 1998 was also approved by the Governor of East Kalimantan through a Governor Decree No. 466/1999.

${ }^{10}$ Law No. 25/1999 Article 6:5.

${ }^{11}$ For the short time the export tax policy was active (February to June 2001) a total of $62,897.40 \mathrm{~m} 3$ timber was exported, bringing in foreign exchange of of US\$ 7,105,923.41 and raising Rp. 12.9 billion in export tax. The Regional Income Office reported that they received Rp. 7.6 billion from the exported log.

${ }^{12}$ Data not available for Sekatak, Sesayap, Sesayap Hilir, Tanah Lia and Bunyu subdistricts.

${ }^{13}$ Ministerial Decree No. 126/2003 on Forest Product Administration.

${ }^{14}$ Perda No. 17/2000 Articles 10 - 11.

${ }^{15}$ SK Bupati No. 196/2000.

${ }^{16}$ Perda No. 16/2000 and Bupati's Decree No. 66/2001.

17 District Forestry Office's circulation letter No. 522.21/67/DISHUT/II/2003 dated 14 January 2003

${ }^{18}$ Bupati's Decree No. 522/86/Ek.Proda/2004.

${ }^{19}$ See "Decentralisation and Forests in Indonesia Case Study 12, CIFOR, 2004".

${ }^{20}$ Radar Tarakan, 6 June 2004.

${ }^{21}$ These issues were raised by stakeholders in a series of the meetings and workshops on the district's Working Group on Forest and Land Rehabilitation (KKRHL) held in 2003 and 2004.

Samsu of Yayasan Pionir Bulungan; Dt. Iman Suramenggala of Bulungan District Forestry Service; Yan Ngau of Bulungan District Parliament (DPRD); and Heru Komarudin and Siân McGrath of CIFOR prepared this Decentralisation Brief drawn from the report The Impacts of Decentralised Forestry Policies on Regional Finance, Local Communities and Spatial Planning - a case study of Bulungan district, East Kalimantan. This work has been funded by ACIAR and DFID under the project: Can Decentralisation Work for Forests and the Poor? The opinions expressed herein are those of the authors and do not necessarily reflect the views of funding agency.
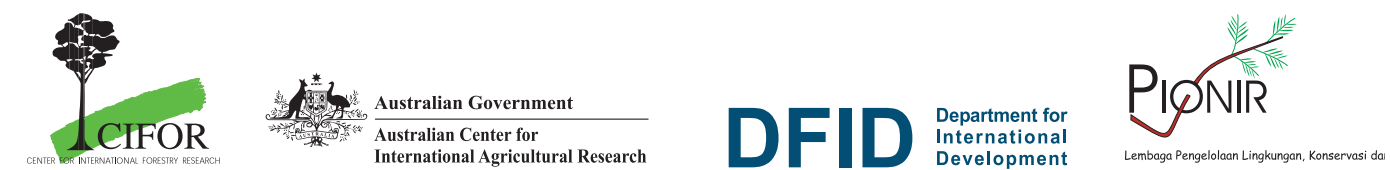

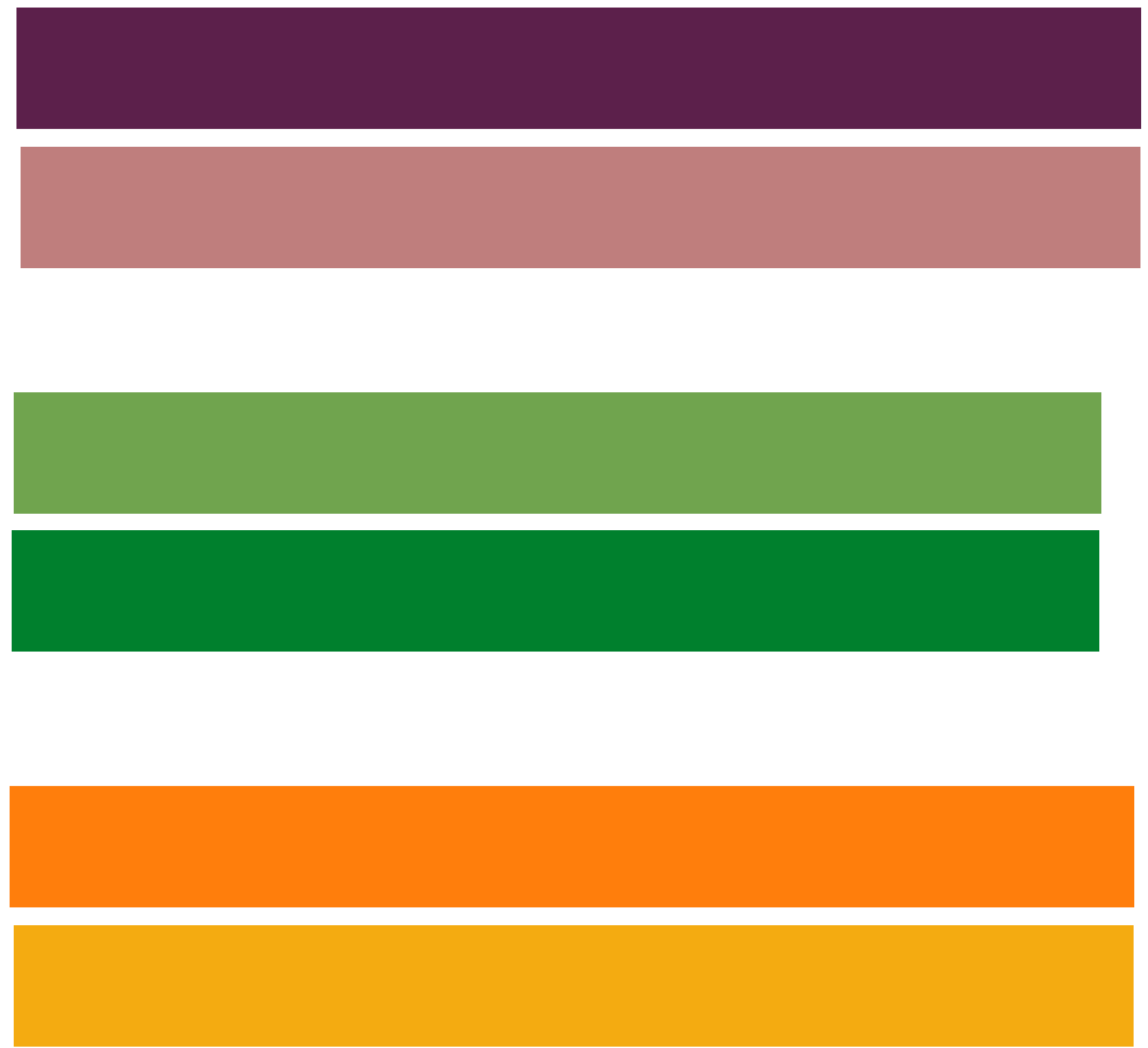